\title{
From Imidazole toward Imidazolium Salts and N-Heterocyclic Carbene Ligands: Electronic and Geometrical Redistribution
}

\author{
Alba Vellé, Andrea Cebollada, Ramón Macías, Manuel Iglesias, María Gil-Moles, ${ }^{\dagger}$ \\ and Pablo J. Sanz Miguel*(1) \\ Departamento de Química Inorgánica, Instituto de Síntesis Química y Catálisis Homogénea (ISQCH), Universidad de \\ Zaragoza-CSIC, 50009 Zaragoza, Spain
}

\section{Supporting Information}

ABSTRACT: Investigations dealing with $\mathrm{N}$-heterocyclic carbenes and their derivatives are usually centered on the influence that they exert by acting as catalysts, ionic liquids, or metallodrugs and consequently on their capabilities to tune the properties and reactivity of these systems. In this context, we aimed to focus on the internal molecular changes undergone by imidazole derivatives, from electronic and geometrical points of view. This work represents an empirical evidence of the molecular modifications that an imidazole skeleton undergoes upon protonation, alkylation, and metalation.

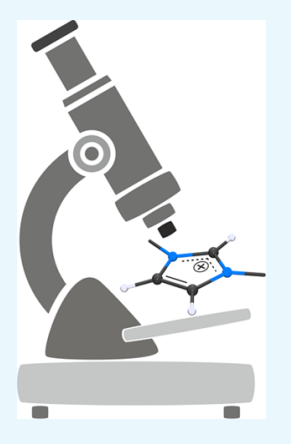

\section{INTRODUCTION}

$\mathrm{N}$-Heterocyclic carbenes (NHCs) have emerged along the last quarter century as versatile tools with numerous applications that have made a considerable impact in chemistry, physics, and material science. ${ }^{1-6}$ There is a wide variety of symmetric and asymmetric NHC ligands bearing protons, alkyl, or aryl substituents at the nitrogen atoms. Among other uses, NHCs are excellent ligands capable of stabilizing alkali, alkaline earth, transition, and inner transition metal complexes. ${ }^{7}$ Their strong electron donor ability modifies the electronic properties of the metals, including metallophilicity. 8,9 This enhancement of electron density is systematically exploited in homogeneous and heterogeneous catalysis ${ }^{10,11}$ and in the design of potential antitumor metallodrugs. ${ }^{12}$ NHCs also exhibit an interesting main-group reaction chemistry that involves, for example, the stabilization of $\mathrm{E}-\mathrm{E}$ multiple bonds, activation of $\mathrm{E}-\mathrm{E}$ bonds, ring expansion reactions, and so forth. ${ }^{13}$ In addition, NHCs can be deposited on surfaces as anchoring or mobility units; ${ }^{14}$ they have also been applied directly as organocatalysts, facilitating the synthesis of sophisticated organic synthons, molecules, and metal-free polymers. ${ }^{15,16}$

Given this background, it is evident that the importance of imidazoles and their cationic imidazolium derivatives results to a large extent from the fact that these heterocyclic rings are reactants in the synthesis of NHCs. However, imidazoles and imidazolium salts are important in their own right. Thus, imidazole rings are part of many natural products, and this building block is present in significant biological bases and in drugs of physiological activity. Likewise, imidazolium derivatives form ionic liquids with a variety of substituents and anions, which are commonly considered as green solvents and utilized for a wide range of applications. ${ }^{17}$
It is clear that the many chemical facets of imidazole and imidazolium salts make them important and ubiquitous compounds. It is, therefore, quite surprising that there is a lack of studies dealing with the structural and spectroscopic characteristics of imidazole/imidazolium systems, in a systematic manner, emphasizing, for example, the changes that the aromatic $\mathrm{N}$-heterocyclic ring may undergo upon protonation or alkylation to form the imidazolium precursors. These kinds of comparative studies are usually biased because imidazole/ imidazolium systems are often regarded as mere intermediates in the pathway toward the synthesis of NHCs.

In this work, we have focused on exploring this last topic, as detailed studies of this kind are scarce. Herein, we, therefore, report a thorough study of the structural, spectroscopic, and electronic properties of a stepwise synthesized imidazole and of two imidazolium derivatives (Scheme 1). In particular, our synthetic approach includes: (i) a neutral imidazole derivative, 1-(2-phenoxyethyl)imidazole (1a, PhOEtIm); (ii) its protonated R,H-NHC form, 1-(2-phenoxyethyl)imidazolium tetrafluoroborate (1b, [HPhOEtIm] $\left.\mathrm{BF}_{4}\right)$; (iii) the corresponding bisNHC salt, methylenebis(N-2-phenoxyethyl)imidazolium diiodide (2, [ $\mathrm{H}_{2}$ bisPhOEtIm $] \mathrm{I}_{2}$ ); and (iv) the palladium complex, $\left[\mathrm{Pd}\left(\right.\right.$ bisPhOEtIm) $\left.\mathrm{I}_{2}\right]$ (3), which incorporates a methylenebis(N-2-phenoxyethyl)imidazol-2-ylidene unit (bisPhOEtIm) as the chelating ligand.

Received: February 7, 2017

Accepted: March 30, 2017

Published: April 10, 2017 
Scheme 1. Formation of Compounds 1a, 1b, 2, and 3

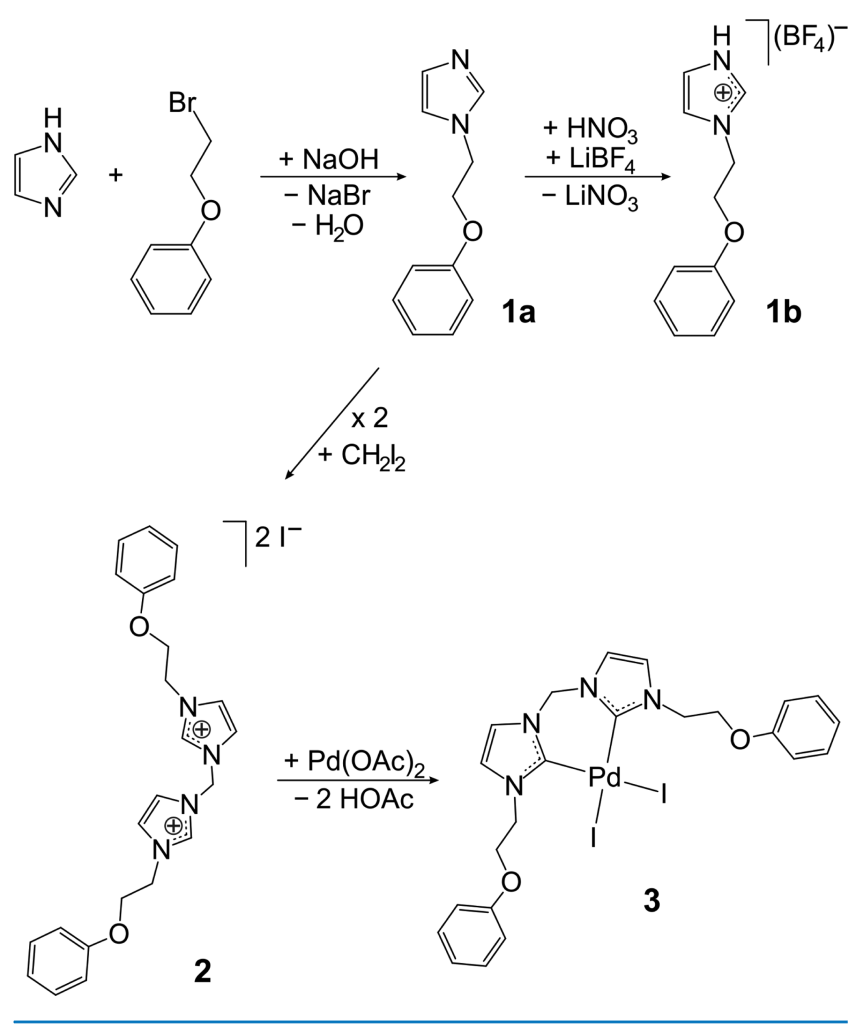

\section{RESULTS AND DISCUSSION}

PhOEtIm (1a) and [HPhOEtIm]BF 4 (1b). Synthesis of 1(2-phenoxyethyl)imidazole (PhOEtIm) (1a) was carried out starting from imidazole, which was deprotonated in refluxing acetonitrile with excess $\mathrm{NaOH}$. After treatment with 2phenoxyethylbromide, followed by separation and washing routines, PhOEtIm was obtained as a white precipitate and recrystallized. The ${ }^{1} \mathrm{H}$ NMR spectrum of 1 a (r.t., $\left.\left(\mathrm{CD}_{3}\right)_{2} \mathrm{CO}\right)$ shows the $\mathrm{H} 2$ proton signal as a singlet $(7.63 \mathrm{ppm})$ and the $\mathrm{H} 5$ and $\mathrm{H} 4$ protons as pseudotriplets centered at 7.28 and 7.19 ppm, respectively. The phenyl ring protons are observed as multiplets (centered at 7.28 and $6.94 \mathrm{ppm}$ ), and the ${ }^{1} \mathrm{H}$ signals assigned to the $\mathrm{N}-\mathrm{CH}_{2}$ and $\mathrm{CH}_{2}-\mathrm{O}$ resonances appear as multiplets at 4.44 and $4.29 \mathrm{ppm}$, respectively. A complete NMR characterization $\left({ }^{1} \mathrm{H}\right.$ NMR, ${ }^{13} \mathrm{C}\left\{{ }^{1} \mathrm{H}\right\}$-APT NMR, ${ }^{1} \mathrm{H}-{ }^{13} \mathrm{C}$ heteronuclear single quantum correlation (HSQC)/heteronuclear multiple bond correlation $(\mathrm{HMBC}))$ is provided in the Supporting Information.

A view of compound 1a is given in Figure 1, showing the imidazole ring $\mathrm{N}$-connected to the 2-phenoxyethyl unit. Table 1 lists bond lengths and angles, determined by X-ray crystallography, for compound $\mathbf{1 a}$, together with compounds $\mathbf{1 b}$ and $\mathbf{2}$,

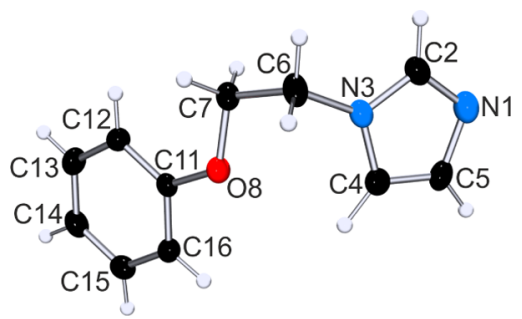

Figure 1. ORTEP-type representation of PhOEtIm (1a). and the density functional theory (DFT)-calculated data for the optimized structures, Ia, Ib, and II. It should be noted that the hydrogen atoms in 1a were observed in the difference Fourier map. Both imidazole and phenyl rings form a dihedral angle of $56.82(9)^{\circ}$, whereas the $\mathrm{N} 3-\mathrm{C} 6-\mathrm{C} 7-\mathrm{O} 8$ torsion angle was found to be $63.8(3)^{\circ}$. In the crystal, there are no strong intermolecular interactions. The $\mathrm{C} 2(\mathrm{H}) \cdots \mathrm{N}^{\prime}$ distance at 3.364(4) $\AA$ is the shortest intramolecular contact within the crystal lattice; but this appears to be too long to be regarded as even a weak hydrogen bonding interaction between two neighboring 1a molecules.

Protonation of PhOEtIm was achieved by stepwise addition of $\mathrm{HNO}_{3}$ to an aqueous solution of 1a. ${ }^{1} \mathrm{H}$ NMR monitoring experiments in deuterated water revealed a $\mathrm{pD}$-dependent shift of the proton signals upon the stepwise protonation (Supporting Information). The $\mathrm{p} K_{\mathrm{a}}$ value of the $\mathrm{N} 1$ site in the PhOEtIm/HPhOEtIm ${ }^{+}$equilibrium was found to be $6.56 \pm$ 0.03 (value converted to $\mathrm{H}_{2} \mathrm{O}$ ). ${ }^{18}$ For comparison, we also measured the acid dissociation constant of the related compound, 1-methylimidazole, obtaining a $\mathrm{pK}_{\mathrm{a}}$ value of 7.18 \pm 0.02 in $\mathrm{H}_{2} \mathrm{O}$. This value is similar to previously reported approximations. ${ }^{19}$ Thus, as expected, the substituents have an evident influence on the acidity constant of imidazoles, which is a reflection of their electronic distribution and geometry.

After addition of $\mathrm{LiBF}_{4}$ to a solution of $1 \mathrm{a}$, acidified with $\mathrm{HNO}_{3}$, colorless crystals of $[\mathrm{HPhOEtIm}] \mathrm{BF}_{4}(\mathbf{1 b})$ were isolated. We recorded ${ }^{1} \mathrm{H}$ NMR spectra of $\mathbf{1 a}$ and $\mathbf{1 b}$ from crystalline samples in $\left(\mathrm{CD}_{3}\right)_{2} \mathrm{CO}$ (Figure 2). There is a large downfield shift in the proton resonances upon protonation of the $\mathrm{N}$-heterocyclic ring, 1a, demonstrating an important electronic change in the molecule. The most affected protons are $\mathrm{H} 2(\Delta \delta=1.55 \mathrm{ppm}), \mathrm{H} 5(\Delta \delta=0.62 \mathrm{ppm})$, and $\mathrm{H} 4(\Delta \delta=$ $0.56 \mathrm{ppm})$, although aliphatic $\left(\Delta \delta=0.43 \mathrm{ppm}, \mathrm{N}-\mathrm{CH}_{2}\right.$ and $\left.0.22 \mathrm{ppm}, \mathrm{CH}_{2}-\mathrm{O}\right)$ and, to a lesser extent, phenyl protons $(\Delta \delta=0.01-0.03 \mathrm{ppm}$ ) are also altered (Supporting Information).

The crystal structure analysis of $\mathrm{HPhOEtIm}^{+}$(cation $\mathbf{1 b}$ ) revealed notable structural modifications when compared to that of $\mathbf{1 a}$ (Table 1). A view of cation $\mathbf{1} \mathbf{b}$ is depicted in Figure 3. An interesting aspect concerns the symmetrization undergone by the imidazolium ring upon protonation, involving its bond distances and angles. These structural changes can be rationalized invoking the resonant forms of an imidazole ring versus an imidazolium ring (Scheme 2). Both $\mathrm{C} 2-\mathrm{N}$ bond distances are almost identical in $\mathbf{1 b}$ : the $\mathrm{C} 2-\mathrm{N} 3$ distance becomes significantly shorter (from 1.356(3) $\AA$ in 1a to $1.328(2) \AA$ in $\mathbf{1 b})$, whereas the $\mathrm{N} 1(\mathrm{H})-\mathrm{C} 2$ length is $1.326(3)$ $\AA$ in $\mathbf{1 b}(1.316(3) \AA$ in 1a). These structural attributes reflect the electronic changes that the imidazole ring suffers upon protonation at the $\mathrm{N} 1$ atom. The proton changes the aromatic character of the N-heterocyclic ring. Thus, the structural and NMR spectroscopic variation of the neutral versus alkylated or protonated systems may be rationalized as a change in the aromaticity of the ring, with the protonated and alkylated cationic species being more aromatic than the neutral imidazole precursors (vide infra).

In addition, it is worth mentioning here that, although the C4-C5 connection is usually depicted by a double line (Scheme 2, right), this bond is slightly elongated with respect to the $\mathrm{C}=\mathrm{C}$ bond distances typically found in alkenes (ca. 1.34 $\AA$ ). On the basis of the discussion above, this elongation is the result of the aromatic character of the $\mathrm{N}$-heterocyclic pentagonal rings in imidazoles, imidazolium, and carbenes. 
Table 1. Selected Interatomic Distances $[\AA ̊]$ and Angles [deg] for Compounds 1a, 1b, and 2 and for Their DFT-Optimized Models Ia, Ib, and II

\begin{tabular}{|c|c|c|c|}
\hline & $1 \mathrm{a} / \mathrm{Ia}$ & $1 b / I b$ & $2 / \mathrm{II}$ \\
\hline $\mathrm{N} 1-\mathrm{C} 2$ & $1.316(4) / 1.306$ & $1.326(3) / 1.315$ & $1.348(2) / 1.323$ \\
\hline $\mathrm{C} 2-\mathrm{N} 3$ & $1.356(3) / 1.340$ & $1.328(2) / 1.317$ & $1.327(2) / 1.314$ \\
\hline $\mathrm{N} 3-\mathrm{C} 4$ & $1.376(3) / 1.357$ & $1.377(2) / 1.361$ & $1.378(2) / 1.362$ \\
\hline $\mathrm{C} 4-\mathrm{C} 5$ & $1.355(4) / 1.361$ & $1.340(3) / 1.351$ & $1.348(3) / 1.348$ \\
\hline $\mathrm{C} 5-\mathrm{N} 1$ & $1.383(3) / 1.358$ & $1.373(3) / 1.355$ & $1.379(3) / 1.362$ \\
\hline $\mathrm{C} 2-\mathrm{N} 1-\mathrm{C} 5$ & $104.6(2) / 104.7$ & $109.15(18) / 109.87$ & $109.13(16) / 109.31$ \\
\hline $\mathrm{N} 1-\mathrm{C} 2-\mathrm{N} 3$ & $112.3(2) / 112.4$ & $107.93(17) / 107.77$ & $107.27(17) / 107.92$ \\
\hline $\mathrm{C} 2-\mathrm{N} 3-\mathrm{C} 4$ & $106.7(2) / 107.1$ & $108.82(17) / 109.18$ & $109.56(16) / 109.33$ \\
\hline $\mathrm{N} 3-\mathrm{C} 4-\mathrm{C} 5$ & $105.9(2) / 105.3$ & $107.10(18) / 106.81$ & $107.21(17) / 106.47$ \\
\hline $\mathrm{N} 1-\mathrm{C} 5-\mathrm{C} 4$ & $110.6(2) / 110.6$ & $106.99(18) / 106.36$ & $106.82(17) / 106.97$ \\
\hline
\end{tabular}

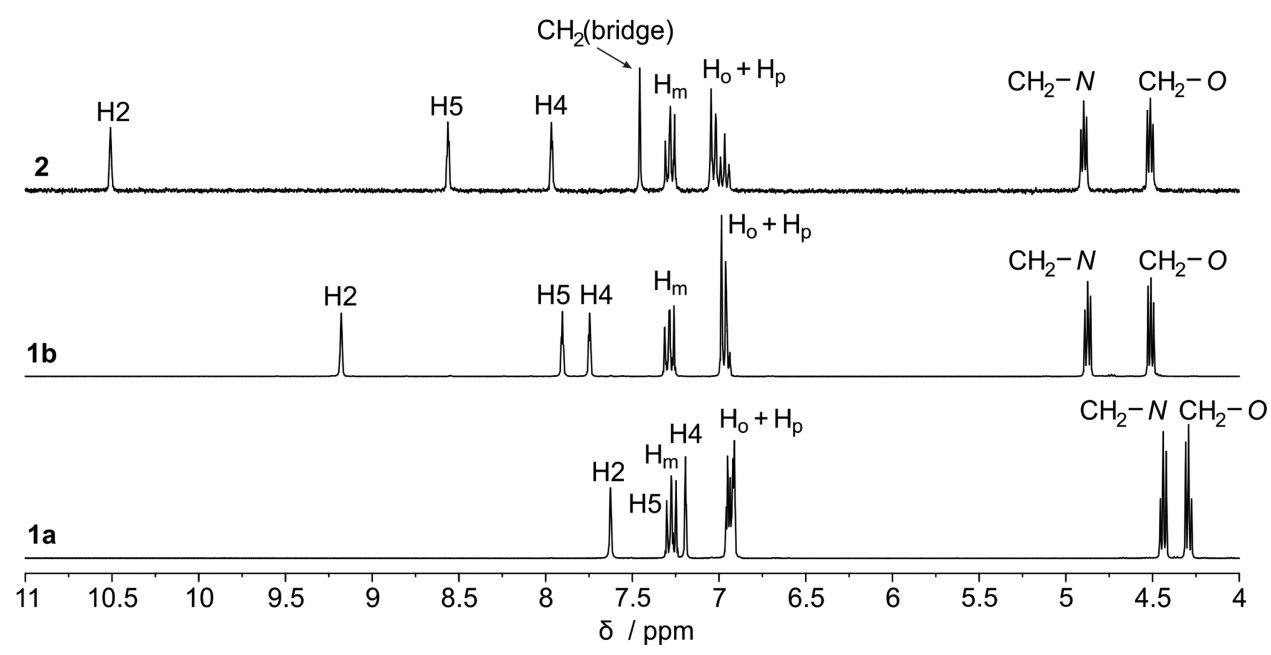

Figure 2. ${ }^{1} \mathrm{H}$ NMR spectra in $\left(\mathrm{CD}_{3}\right)_{2} \mathrm{CO}$ for compounds $\mathbf{1 a}, \mathbf{1} \mathbf{b}$, and $\mathbf{2}$.

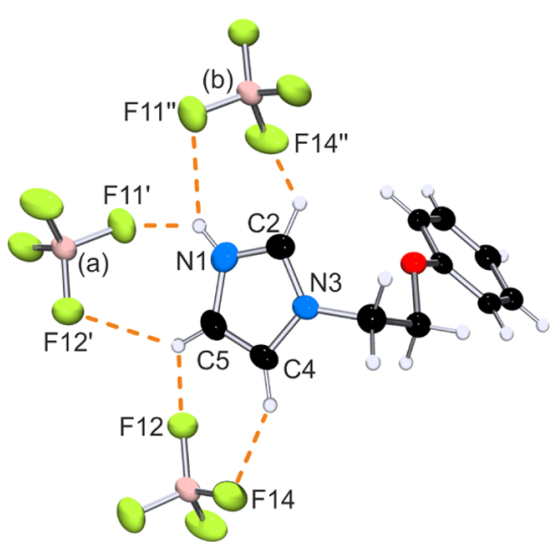

Figure 3. View of short contacts between the imidazolium cation and three neighboring $\mathrm{BF}_{4}^{-}$anions in the crystal of $\mathbf{1 b}$. Symmetry operations: (a) $x, 1+y, z$; (b) $2-x, 1-y,-z$.

Scheme 2. Protonation of an Imidazole Derivative: Resonant Changes in the Ring<smiles>[R]n1c([2H])cc[n+]1[B]</smiles>

Likewise, $\mathrm{N} 1-\mathrm{C} 2$ and $\mathrm{C} 2-\mathrm{N} 3$ bond distances (typically represented by a combination of solid and dashed lines) are between the typical values found for $\mathrm{C}-\mathrm{N}$ single $(1.47 \AA)$ and $\mathrm{C}=\mathrm{N}$ double $(1.27 \AA)$ bonds, ${ }^{20}$ being closer from the singlebond value, reflecting again the effects of the electronic delocalization in the pentagonal rings. On the basis of the structural characteristics of the imidazole and imidazolium rings and their aromatic character (see below), a circle within the ring appears to be appropriate to illustrate the bonding within these N-heterocyclic rings. It is not surprising, therefore, that some authors prefer this latter representation for imidazole, imidazolium, and carbene molecules.

As commented above, endocyclic ring angles are also influenced by protonation. The presence of a proton at $\mathrm{N} 1$ widens by $+4.6(2)^{\circ}$ the corresponding $\mathrm{C} 2-\mathrm{N} 1-\mathrm{C} 5$ angle: $1 \mathrm{a}$, $104.6(2)^{\circ} ; \mathbf{1 b}, 109.15(18)^{\circ}$. This structural change could be rationalized from the point of view of the valence shell electron pair repulsion (VSEPR) theory that assigns a higher repulsion power to lone electron pairs than to sigma bonds; therefore, the protonation at the $\mathrm{N} 1$ atom reduces the steric repulsion, leading to the observed increase in the $\mathrm{C} 2-\mathrm{N} 1-\mathrm{C} 5$ angle. This structural phenomenon has been typically observed in imidazole and pyrimidine rings of nucleobases and actually serves as diagnostic for the presence of protonation in these systems. $^{21,22}$ In contrast, both adjacent $\mathrm{N} 1-\mathrm{C} 2-\mathrm{N} 3$ and $\mathrm{N} 1-\mathrm{C} 5-\mathrm{C} 4$ angles decrease, displaying differences of $-4.4(2)^{\circ}\left(1 \mathbf{a}: 112.3(2)^{\circ} ; \mathbf{1 b}: 107.93(17)^{\circ}\right)$ and $-3.6(2)^{\circ}$ (1a: $110.6(2)^{\circ}$; 1 b: $\left.106.99(18)^{\circ}\right)$, respectively. 
Cation $\mathbf{1 b}$ exhibits an amphiphilic nature: a polar central imidazolium core connected to the nonpolar hydrophobic phenyl ring. Figure 3 outlines contacts involving the imidazolium cation of $\mathbf{1 b}$ that is surrounded by three $\mathrm{BF}_{4}^{-}$ anions. The acidic proton at the $\mathrm{N} 1$ site forms hydrogen bonds with two symmetry-related counter $\mathrm{BF}_{4}^{-}$anions, namely,

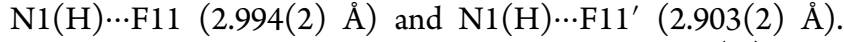
Additional intermolecular $\mathrm{C}-\mathrm{F}$ distances are $\mathrm{C} 4(\mathrm{H}) \cdots \mathrm{F} 14$

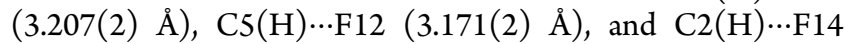
(3.169(2) $\AA$ ). These latter contacts are too long to be regarded as $\mathrm{C}-\mathrm{H} \cdots \mathrm{F}$ hydrogen bonds, although they could provide some weak lattice stabilization. It should be noted that the crystal structure of $\mathbf{1 b}$ does not exhibit substantial intermolecular interactions between neighboring cations.

$\left[\mathrm{H}_{2}\right.$ bisPhOEtIm] $\mathrm{I}_{2}$ (2). The bisimidazolium salt, $\left[\mathrm{H}_{2}\right.$ bisPhOEtIm $] \mathrm{I}_{2}$ (2), was prepared from the reaction between $\mathrm{CH}_{2} \mathrm{I}_{2}$ and 1a. Upon recrystallization in acetonitrile, colorless crystals were isolated and studied. A complete NMR characterization of salt $2\left({ }^{1} \mathrm{H}\right.$ NMR, ${ }^{13} \mathrm{C}\left\{{ }^{1} \mathrm{H}\right\}$-APT NMR, ${ }^{1} \mathrm{H}-{ }^{13} \mathrm{C}$ HSQC/HMBC) is provided in the Supporting Information. The ${ }^{1} \mathrm{H}$ NMR spectrum of 2 [r.t., $\left(\mathrm{CD}_{3}\right)_{2} \mathrm{CO}$ ] conforms to the two-fold symmetry of the bisimidazolium dication. Figure 2 illustrates that the imidazolium protons in $\mathbf{2}$ suffer a significant downfield shift with respect to the resonances of $\mathbf{1 b}$ : $\mathrm{H} 2$ (10.51 ppm), H5 (8.56 ppm), and H4 (7.96 ppm). These data suggest that the $\mu-\mathrm{CH}_{2}$ bridge (singlet at $\left.\delta_{\mathrm{H}} 7.46 \mathrm{ppm}\right)$ in 2 exerts a higher deshielding effect on the protons of the imidazolium ring than on the proton in compound $\mathbf{1 b}$. Alternatively, the observed proton chemical shifts could be ascribed to different secondary interactions between the cation and the anion as revealed in the crystal structures of both salts. It is noteworthy that no significant ${ }^{1} \mathrm{H}$ chemical shift variation between $\mathbf{1 b}$ and $\mathbf{2}$ is observed for the aliphatic and phenyl protons, indicating that, in this region, the effect of protonation at $\mathrm{N} 1$ seems to be similar to the bridging methylenation.

Iodide salt 2 of the $\mathrm{H}_{2}$ bisPhOEtIm ${ }^{2+}$ cation crystallizes in the centrosymmetric $\mathrm{C} 2 / \mathrm{c}$ space group (Figure 4 ), with the

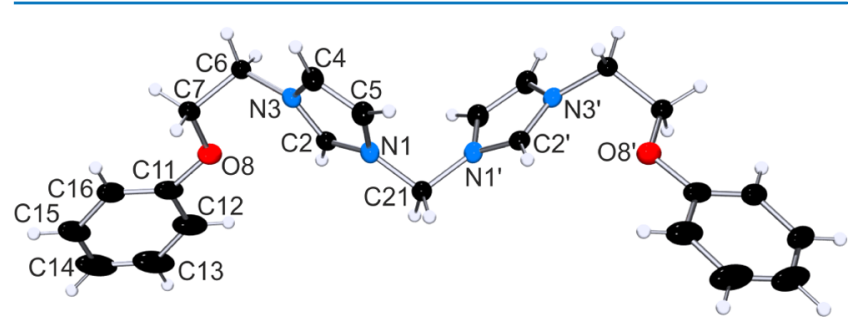

Figure 4. View of the $\mathrm{H}_{2}$ bisPhOEtIm ${ }^{2+}$ dication in iodide salt 2 .

bridging methylene group lying at the inversion center (C21 in Figure 4). Selected crystallographically determined distances and angles are listed in Table 1 together, for comparison, with those calculated by DFT. The imidazolium dication in salt $\mathbf{2}$ is transoid disposed, with a dihedral angle between both imidazolium rings that approaches $90^{\circ}\left(86.91(6)^{\circ}\right)$. The $\mathrm{N} 1-\mathrm{C} 21-\mathrm{N} 1^{\prime}$ angle between them is $107.8(2)^{\circ}$, close to the expected tetrahedral angle supported by the bridging carbon atom. In addition, the aromatic tails of the phenoxyethyl substituents display a dihedral angle of $52.29(9)^{\circ}$ with the imidazolium rings. The $\mathrm{N} 3-\mathrm{C} 6-\mathrm{C} 7-\mathrm{O} 8$ torsion angle is $68.8(2)^{\circ}$. These angle values resemble those found in the crystal structures of $\mathbf{1 a}$ and $\mathbf{1 b}$.
The geometry variations found in the imidazolium rings of compound $\mathbf{2}$ follow the same trend discussed above for salt $\mathbf{1} \mathbf{b}$. Thus, the N1-C2 bond distance is longer (1.348(2) $\AA$ ) in 2 than in $\mathbf{1 a}$ and $\mathbf{1 b}$ and (by chance) identical to that of C4-C5. Similarly, both N3-C4 and $\mathrm{C} 5-\mathrm{N} 1$ bond lengths in 2 are identical (Table 1). Besides, the $\mathrm{C} 2-\mathrm{N} 3$ bond distance does not vary with respect to that in both salts $\mathbf{1 b}$ and $\mathbf{2}$ and is shorter than the neighboring $\mathrm{N} 1-\mathrm{C} 2$ bond distance. Regarding the ring angles, no significant variations are observed between $\mathbf{1 b}$ and $\mathbf{2}$. Such changes are reflected in the aromaticity of the imidazole ring (see DFT Calculations section).

As in the case of $\mathbf{1 b}$, dication $\mathbf{2}$ displays an amphiphilic nature. The crystal packing of $\mathbf{2}$ is dominated by anion/cation interactions. Interestingly, these interactions involve mainly the imidazolium rings and the $\mu-\mathrm{CH}_{2}$ bridge, demonstrating that, as expected, the positive charge is localized around the imidazolium head of the molecule. Figure 5 shows the

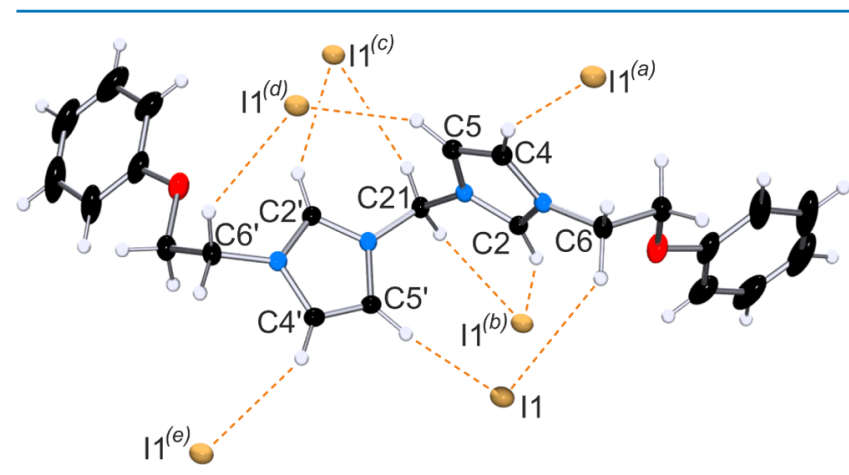

Figure 5. Representation of the $\mathrm{C}(\mathrm{H}) \cdots \mathrm{I}$ interactions of dication 2 with symmetry-related iodide anions. Symmetry operations: (a) $+x$, $-y, 0.5+z$; (b) $+x, 1+y, z$; (c) $-x, 1+y, 0.5-z$; (d) $-x,+y, 0.5-z$; (e) $-x,-y,-z$.

$\mathrm{C}(\mathrm{H}) \cdots \mathrm{I}$ interactions involving the cationic imidazolium rings. Although these interactions are relatively long (C5, 3.777(2) $\AA$;

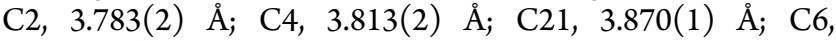
$3.903(2) \AA)$, and the protons involved are not very acidic, they seem to exhibit sufficient hydrogen-bond-donor capabilities to interact with the I1 anions in the crystal lattice. In any case, these short contacts are driven by packing and electrostatic effects (Supporting Information). In this regard, the large proton chemical shifts observed for $\mathrm{H} 2$ and $\mathrm{H} 5$ could be perhaps rationalized as the result of the secondary cation/anion interactions in solution.

[Pd(bisPhOEtIm) $\left.I_{2}\right]$ (3). The synthesis of 3 was carried out by the addition of $\mathbf{2}$ to a solution of palladium acetate in acetone. Immediately, the solution changed color from orange to dark brown-orange, and after $24 \mathrm{~h}$ stirring at room temperature, the solution turned progressively deep orange. The product was isolated by precipitation with ether, followed by filtration. Recrystallization from acetone/ether afforded compound 3 in $80 \%$ yield. Suitable crystals for X-ray crystallography were grown by slow diffusion of ether into a dichloromethane solution of complex 3 at room temperature.

The ${ }^{1} \mathrm{H}$ NMR spectrum of 3 in deuterated acetone (r.t., Supporting Information) shows variations when compared to that of $\mathbf{1 a}, \mathbf{1 b}$, and $\mathbf{2}$. Metal coordination at the $\mathrm{C} 2$ site, with the subsequent substitution of the $\mathrm{C} 2(\mathrm{H})$ proton, yields a high field shift of the proton signals, in particular, of those placed in the immediate vicinity of the $\mathrm{Pd}^{\mathrm{II}}$ ion. Thus, the $\mathrm{H} 5(7.60 \mathrm{ppm})$ and $\mathrm{H} 4(7.38 \mathrm{ppm})$ protons appear in the spectra of $\mathbf{3}$ as 
doublets, displaying a $\Delta \delta$ compared to those of imidazolium salt 2 of -0.96 and -0.59 ppm, respectively. Phenyl proton multiplets show minor variations and are centered at 7.23 (meta), 6.90 (para), and 6.84 (ortho) ppm, respectively. The $\mathrm{CH}_{2}$ bridging unit exhibits an $\mathrm{AB}$ system, ${ }^{8}$ centered at 6.45 $\operatorname{ppm}(\Delta \delta=-1.01 \mathrm{ppm}$, in comparison with 2$)$, whereas the $\mathrm{N}-\mathrm{CH}_{2}$ and $\mathrm{CH}_{2}-\mathrm{O}$ are shown in the 4.2-5.2 ppm range. Regarding the ${ }^{13} \mathrm{C}\left\{{ }^{1} \mathrm{H}\right\}$ NMR spectra, metalation of the $\mathrm{C} 2$ sites produces an expected substantial shift of this resonance, from the range of $137.5-138.8 \mathrm{ppm}(\mathrm{C} 2$ sites in $\mathbf{1 a}-\mathbf{c})$ to $169.1 \mathrm{ppm}$ (C2 site in 3). A complete NMR characterization is available in the Supporting Information.

The crystal structure of compound 3 shows a rather distorted square-planar coordination of the palladium ion, which incorporates a chelating bisPhOEtIm unit and two iodido ligands (Figure 6). Salient intramolecular distances and angles

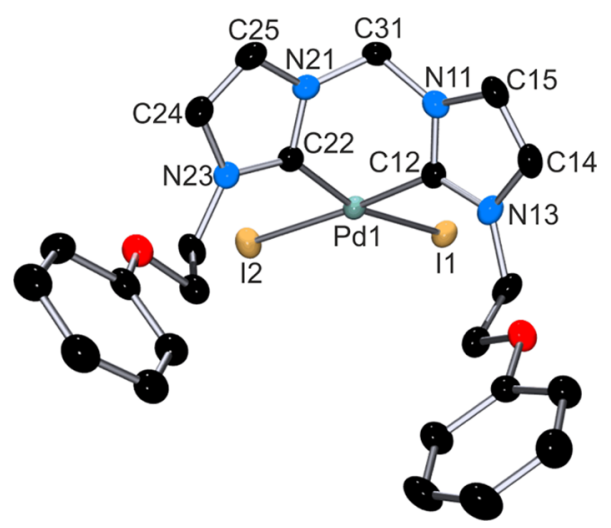

Figure 6. View of complex $\left[\mathrm{Pd}(\right.$ bisPhOEtIm $\left.) \mathrm{I}_{2}\right]$ (3).

Table 2. Selected Interatomic Distances $[\AA]$ and Angles [deg] in Compound 3

\begin{tabular}{lrlr}
$\mathrm{Pd} 1-\mathrm{C} 12$ & $1.988(3)$ & $\mathrm{Pd} 1-\mathrm{C} 22$ & $1.983(3)$ \\
$\mathrm{Pd} 1-\mathrm{I} 1$ & $2.6373(3)$ & $\mathrm{Pd} 1-\mathrm{I} 2$ & $2.6465(4)$ \\
$\mathrm{N} 11-\mathrm{C} 12$ & $1.342(4)$ & $\mathrm{N} 21-\mathrm{C} 22$ & $1.358(4)$ \\
$\mathrm{C} 12-\mathrm{N} 13$ & $1.346(4)$ & $\mathrm{C} 22-\mathrm{N} 23$ & $1.342(4)$ \\
$\mathrm{N} 13-\mathrm{C} 14$ & $1.379(4)$ & $\mathrm{N} 23-\mathrm{C} 24$ & $1.404(4)$ \\
$\mathrm{C} 14-\mathrm{C} 15$ & $1.349(5)$ & $\mathrm{C} 24-\mathrm{C} 25$ & $1.340(5)$ \\
$\mathrm{C} 15-\mathrm{N} 11$ & $1.391(4)$ & $\mathrm{C} 25-\mathrm{N} 21$ & $1.385(4)$ \\
$\mathrm{N} 11-\mathrm{C} 31$ & $1.457(4)$ & $\mathrm{N} 21-\mathrm{C} 31$ & $1.461(4)$ \\
$\mathrm{C} 12-\mathrm{Pd} 1-\mathrm{C} 22$ & $82.45(13)$ & $\mathrm{C} 12-\mathrm{Pd} 1-\mathrm{I} 2$ & $174.46(9)$ \\
$\mathrm{C} 12-\mathrm{Pd} 1-\mathrm{I} 1$ & $90.93(9)$ & $\mathrm{C} 22-\mathrm{Pd} 1-\mathrm{I} 1$ & $164.62(9)$ \\
$\mathrm{C} 22-\mathrm{Pd} 1-\mathrm{I} 2$ & $92.01(9)$ & $\mathrm{I} 1-\mathrm{Pd} 1-\mathrm{I} 2$ & $94.430(11)$ \\
$\mathrm{C} 12-\mathrm{N} 11-\mathrm{C} 15$ & $111.4(3)$ & $\mathrm{C} 22-\mathrm{N} 21-\mathrm{C} 25$ & $111.3(3)$ \\
$\mathrm{N} 11-\mathrm{C} 12-\mathrm{N} 13$ & $105.4(3)$ & $\mathrm{N} 21-\mathrm{C} 22-\mathrm{N} 23$ & $105.0(3)$ \\
$\mathrm{C} 12-\mathrm{N} 13-\mathrm{C} 14$ & $110.1(3)$ & $\mathrm{C} 22-\mathrm{N} 23-\mathrm{C} 24$ & $110.3(3)$ \\
$\mathrm{N} 13-\mathrm{C} 14-\mathrm{C} 15$ & $108.0(3)$ & $\mathrm{N} 23-\mathrm{C} 24-\mathrm{C} 25$ & $107.1(3)$ \\
$\mathrm{N} 11-\mathrm{C} 15-\mathrm{C} 14$ & $105.2(3)$ & $\mathrm{N} 21-\mathrm{C} 25-\mathrm{C} 24$ & $106.3(3)$ \\
\hline
\end{tabular}

are presented in Table 2. The angles $\mathrm{C} 12-\mathrm{Pd} 1-\mathrm{I} 2$ and C22-Pd1-I1 are $174.46(9)$ and $164.62(9)^{\circ}$, respectively. The latter exhibits a clear distortion from linearity that is found in less than $11 \%$ of PdL4 ( $\mathrm{L}=$ any atom) square-planar complexes. $^{a}$

An interesting question concerns the structural modification undergone by the bisPhOEtIm ligand upon $\mathrm{C} 2$ cis-coordination to the palladium ion, which formally represents a substitution of the $\mathrm{C} 2(\mathrm{H})$ protons by a $\mathrm{Pd}^{\mathrm{II}}$ center. First, both imidazole rings change into a mutual cisoid orientation and display a tilt angle of $72.5(1)^{\circ}$, in contrast to the transoid orientation and almost right dihedral angle exhibited in cation 2 . This rotation does not affect the geometry of the bridging $\mathrm{sp}^{3}$ hybridized $\mathrm{CH}_{2}$ unit, with angle and distances involving both pentanuclear rings in compound 3 of $107.3(3)^{\circ}(\mathrm{N} 11-\mathrm{C} 31-\mathrm{N} 21), 1.457(4) \AA$ $(\mathrm{N} 11-\mathrm{C} 31)$, and $1.461(4) \AA(\mathrm{N} 21-\mathrm{C} 31)$, respectively. Corresponding values in 2 were $107.8(2)^{\circ}\left(\mathrm{N} 1-\mathrm{C} 21-\mathrm{N} 1^{\prime}\right)$ and $1.455(2) \AA(\mathrm{N} 1-\mathrm{C} 21)$. In reference to the imidazole geometry, it should be noted that the higher standard deviations exhibited by crystal 3, probably due to the presence of both iodido ligands, hinder a thorough comparison of records. However, some tendencies can be analyzed. Substantial variations include the following: (i) the $\mathrm{C} 2-\mathrm{N} 3$ distances in 3 $(\mathrm{C} 12-\mathrm{N} 13,1.346(4) \AA$; $\mathrm{C} 22-\mathrm{N} 23,1.342(4) \AA)$ are longer than those in $2(1.327(2) \AA)$, namely, they possess a lower double-bond character as a result of the electron density donation to the metal center. (ii) Interestingly, the $\mathrm{N} 1-\mathrm{C} 2-$ $\mathrm{N} 3$ angles are significantly smaller in 3 (N11-C12-N13, $105.4(3)^{\circ}$; N21-C22-N23, $\left.105.0(3)^{\circ}\right)$, when compared to those in $\mathbf{1 a}\left(112.3(2)^{\circ}\right), \mathbf{1 b}\left(107.93(17)^{\circ}\right)$, or $\mathbf{2}\left(107.27(17)^{\circ}\right)$. The decrease of this angle has usually been observed in NHC compounds with transition metals at the $\mathrm{C} 2$ site (Supporting Information). It should be recalled here that a (unprotonated) carbene has a mean $\mathrm{N} 1-\mathrm{C} 2-\mathrm{N} 3$ value of $101^{\circ}, b$ even smaller than that observed in 3. (iii) A side consequence of this is that in 3 the $\mathrm{C} 2-\mathrm{N} 1-\mathrm{C} 5$ angles $\left(\mathrm{C} 12-\mathrm{N} 11-\mathrm{C} 15,111.4(3)^{\circ}\right.$; $\left.\mathrm{C} 22-\mathrm{N} 21-\mathrm{C} 25,111.3(3)^{\circ}\right)$ are even wider than those in $\mathbf{1 b}$ $\left(109.13(16)^{\circ}\right)$.

Following the dictates of the VSEPR, as commented above, the reduction of the $\mathrm{N} 1-\mathrm{C} 2-\mathrm{N} 3$ angle upon deprotonation of the imidazolium salts can be rationalized as a consequence of the higher repulsion power of the electron lone pair at the ylidenic carbon atom versus the $\mathrm{C} 2-\mathrm{H}$ bond. Likewise, upon coordination of the carbene ligands to a metal center, the lone electron pair loses its inherent repulsion capabilities and the angle increases but not as much as that when the carbon is protonated, indicating that the steric effects of the metal center play, as expected, a role in the structural changes of the ligand.

DFT Calculations: Aromaticity. We carried out DFT optimizations (M11L, $311++\mathrm{G}(\mathrm{d}, \mathrm{p})$, SMD water) to study the calculated geometries of compounds $\mathbf{1 a}, \mathbf{1 b}, \mathbf{2}$, and 3 . The resulting optimized intramolecular bond lengths and angles of the corresponding compounds (namely, Ia, Ib, II, and III) are listed in Table 1. The salient coordinates are summarized in the Supporting Information. Overall, calculated arrangements anticipate those obtained experimentally and follow the described trends for the crystal structures: bond angles fit well, although some of the bond length values display minor differences. Thus, the arguments and trends exposed for the crystal structures are also valid here.

An interesting feature concerns a calculated tautomer of $\mathbf{1 a}$, namely $\mathbf{I a}^{*}$, in which the proton at the C2 position in Ia has been shifted to the N1 site in Ia*, allowing for the study of the $\mathrm{C} 2$-carbene atom. As expected, in terms of relative energy, the Ia* tautomer is less stable than Ia $\left(\Delta E=25.7 \mathrm{kcal} \mathrm{mol}^{-1}\right)$. The geometry of $\mathrm{Ia}^{*}$ shows a higher degree of symmetry in the imidazole tautomer ring, when compared to that of Ia (N1C2, $1.347 \AA$; C2-N3, $1.350 \AA$; N3-C4, $1.368 \AA$; C4-C5, $1.347 \AA$; $55-\mathrm{N} 1,1.361 \AA$ ). Furthermore, the N1-C2-N3 angle shows a value of $101.4^{\circ}$, which is in agreement with previously reported examples. $^{a}$ 
As described in this work, protonation or alkylation at the N1 atom of the neutral imidazole ring leads to an increase in the aromatic character of the resulting cationic system. The higher degree of aromaticity is clearly reflected by the observed equilibration in the crystallographic bond distances of the $\mathrm{N}$ heterocyclic rings, and it may be related to the large downfield chemical shift found in the ${ }^{1} \mathrm{H}$ NMR spectra upon protonation and alkylation.

The aromaticity of the optimized models has been estimated by the nucleus-independent chemical shift (NICS). The $\operatorname{NICS}(0)$ value was calculated at the geometrical center of the aromatic ring, whereas NICS $(1)$ are the values obtained at a perpendicular distance of $1.0 \AA$ above the ring center. In our case, due to the low symmetry of the models, the value of NICS(1) depends on which side of the ring is considered, and therefore NICS $(0)$ values have been considered. Most negative NICS values represent a higher aromaticity degree. Table 3 lists

Table 3. NICS Values for Ia, Ia*, Ib, II, and III

\begin{tabular}{lccccc} 
& Ia & Ia* & Ib & II & III \\
$\begin{array}{l}\text { imidazole } \\
\text { NICS }(0)\end{array}$ & -12.5 & -12.9 & -14.3 & -13.8 & -10.4 \\
$\begin{array}{c}\text { phenoxy } \\
\text { NICS }(0)\end{array}$ & -8.9 & -8.8 & -8.9 & -9.1 & -8.6 \\
\hline
\end{tabular}

salient $\operatorname{NICS}(0)$ values for Ia, Ia*, Ib, II, and III. We have calculated the aromaticity at both rings, namely, imidazole and phenoxy. The NICS $(0)$ value for the imidazole ring of Ia is -12.5 , whereas this value for the $\mathrm{Ia}^{*}$ tautomer is -12.9 (Table 3). The protonated form, Ib, exhibits a lower $\operatorname{NICS}(0)$ value, that is, -14.3 , which corresponds, as expected from the experimental data, to a higher level of aromaticity. Alkylation of the imidazole ring in II results in an $\operatorname{NICS}(0)$ value of -13.8 , which is between the neutral forms, $\mathbf{I a} / \mathbf{I a}^{*}$, and the protonated cation, Ib. Complex III, which incorporates a chelating $\mathrm{Pd}^{\mathrm{II}}$ ion at the $\mathrm{C} 2$ sites, displays the lowest aromaticity of the series (NICS $(0),-10.4)$. Thus, symmetrization observed upon protonation and alkylation in the crystal structures results in a higher degree of aromaticity at the imidazole rings. For comparison, the $H, H$-imidazolium cation and the methyl derivative, $\left[\mathrm{Ia}-\mathrm{CH}_{3}\right]^{+}$, were optimized, giving $\mathrm{NICS}(0)$ values of -15.9 and -13.7 . Thus, protonation has a higher effect than alkylation on the aromaticity of the imidazole derivatives, whereas the $\mathrm{C}$-substituents at the endocyclic $\mathrm{N}$ atoms do not substantially affect the aromaticity of the imidazolium rings. In contrast, variations in the aromaticity of phenoxy rings are not remarkable.

\section{CONCLUSIONS}

In summary, we carried out a stepwise synthesis of an imidazole derivative (1a), its protonated imidazolium salt $(\mathbf{1 b})$, the related bisimidazolium salt (2), and a $\mathrm{Pd}^{\mathrm{II}}$-metal complex (3). A comparison between the structure of $1 \mathrm{a}$ and its protonated form $\mathbf{1 b}$ entails a geometrical transformation that can be envisaged as a symmetrization (aromatization) of the imidazole ring. These geometrical variations and the corresponding electronic redistribution are observed by NMR spectroscopy. This trend is further reinforced in the bisimidazolium salt, 2 . Substitution of the $\mathrm{C} 2(\mathrm{H})$ protons of 2 by a metal center, or, namely, coordination of a $\mathrm{PdI}_{2}$ unit to form 3 , results in slight modifications of the geometry of the aromatic rings. The DFTcalculated bond distances and angles in the optimized models are consistent with the X-ray crystallographic data, and NICS criteria reveal that the imidazolium cations exhibit a higher aromaticity than the unprotonated forms and the metal complexes, and, in particular, protonation confers a higher aromaticity level than alkylation.

\section{EXPERIMENTAL SECTION}

Preparations. Reagents and solvents were obtained from commercial sources and used without further purification.

Synthesis of PhOEtIm (1a). Compound 1a was synthesized following reported methods. ${ }^{23}$

Synthesis of [HPhOEtlm]BF 4 (1b). To a saturated solution of $1 \mathrm{a}(402.8 \mathrm{mg}, 2.14 \mathrm{mmol})$ in water, concentrated $\mathrm{HNO}_{3}$ and $\mathrm{LiBF}_{4}(800 \mathrm{mg}, 8.54 \mathrm{mmol})$ were added. After 4 days at $4{ }^{\circ} \mathrm{C}$, crystals of $\mathbf{1 b}$ were picked up $(116 \mathrm{mg}, 0.42 \mathrm{mmol})$ from the beaker. Yield: $20 \% .{ }^{1} \mathrm{H}$ NMR $\left(\left(\mathrm{CD}_{3}\right)_{2} \mathrm{CO}, \delta \mathrm{ppm}, 300 \mathrm{MHz}\right)$ : 9.18 (s, 1H; H2Im), 7.90 (m, 1H; H5Im), 7.75 (m, 1H; H4Im), 7.29 (m, 2H; $\left.\mathrm{H}_{\mathrm{m}} \mathrm{Ph}\right), 6.96\left(\mathrm{~m}, 3 \mathrm{H} ; \mathrm{H}_{\mathrm{p}}+\mathrm{H}_{\mathrm{o}} \mathrm{Ph}\right), 4.87$ $\left(\mathrm{m}, 2 \mathrm{H} ; \mathrm{N}-\mathrm{CH}_{2}\right), 4.51\left(\mathrm{~m}, 2 \mathrm{H} ; \mathrm{CH}_{2}-\mathrm{O}\right) \cdot{ }^{13} \mathrm{C}\left\{{ }^{1} \mathrm{H}\right\}-\mathrm{APT}$ NMR $\left(\left(\mathrm{CD}_{3}\right)_{2} \mathrm{CO}, \delta\right.$ ppm, $\left.75 \mathrm{MHz}\right): 159.0(\mathrm{~s} ; \mathrm{C} \mathrm{Ph}), 137.5$ (s; C2Im), $130.4\left(\mathrm{~s} ; \mathrm{C}_{\mathrm{m}} \mathrm{Ph}\right), 123.6(\mathrm{~s} ; \mathrm{C} 4 \mathrm{Im}), 122.2\left(\mathrm{~s} ; \mathrm{C}_{\mathrm{p}} \mathrm{Ph}\right)$, 120.7 (s; C5Im), $115.4\left(\mathrm{~s} ; \mathrm{C}_{\mathrm{o}} \mathrm{Ph}\right), 66.6\left(\mathrm{~s} ; \mathrm{CH}_{2}-\mathrm{O}\right), 50.0$ (s; $\mathrm{N}-\mathrm{CH}_{2}$ ).

Synthesis of $\left[\mathrm{H}_{2} \text { bisPhOEtIm] }\right]_{2}$ (2). Compound 2 was obtained in an analogous manner to that described previously, ${ }^{24}$ by adding diiodomethane $(0.5 \mathrm{eq})$ to a solution of $1 \mathrm{a}$ in acetonitrile. After refluxing, and the addition of diethyl ether as a precipitating agent, compound $\mathbf{2}$ was isolated as a white solid. Recrystallization in acetonitrile and subsequent cooling $\left(4{ }^{\circ} \mathrm{C}\right)$ resulted in colorless crystals. Yield: $46 \% .{ }^{1} \mathrm{H}$ NMR ( $\mathrm{CD}_{3} \mathrm{CN}, \delta$ ppm, $300 \mathrm{MHz}$ ): 9.90 (s, 2H; H2Im), 8.11 (m, 2H; H5Im), 7.60 (m, 2H; H4Im), 7.30 (m, 4H; $\left.\mathrm{H}_{\mathrm{m}} \mathrm{Ph}\right)$, $6.99\left(\mathrm{~m}, 8 \mathrm{H} ; \mathrm{H}_{\mathrm{p}}+\mathrm{H}_{\mathrm{o}} \mathrm{Ph}+\mathrm{CH}_{2}\right.$-bridge $), 4.62(\mathrm{~m}, 4 \mathrm{H} ; \mathrm{N}-$ $\left.\mathrm{CH}_{2}\right), 4.33\left(\mathrm{~m}, 4 \mathrm{H} ; \mathrm{CH}_{2}-\mathrm{O}\right) .{ }^{13} \mathrm{C}\left\{{ }^{1} \mathrm{H}\right\}-\mathrm{APT}$ NMR $\left(\left(\mathrm{CD}_{3}\right)_{2} \mathrm{CO}, \delta \mathrm{ppm}, 75 \mathrm{MHz}\right): 158.8(\mathrm{~s} ; \mathrm{C} \mathrm{Ph}), 138.8$ (s; C2Im), 130.6 (s; $\left.\mathrm{C}_{\mathrm{m}} \mathrm{Ph}\right), 124.9$ (s; C4Im), 123.2 (s; C5Im), $122.5\left(\mathrm{~s} ; \mathrm{C}_{\mathrm{p}} \mathrm{Ph}\right), 115.6\left(\mathrm{~s} ; \mathrm{C}_{\mathrm{o}} \mathrm{Ph}\right), 66.3\left(\mathrm{~s} ; \mathrm{CH}_{2}-\mathrm{O}\right), 58.5$ (s; $\mathrm{CH}_{2}$-bridge $), 50.8\left(\mathrm{~s} ; \mathrm{N}-\mathrm{CH}_{2}\right)$.

Synthesis of $\left[\mathrm{Pd}\left(\right.\right.$ bisPhOEtlm) $\left.\mathrm{I}_{2}\right]$ (3). A mixture of $\left[\mathrm{Pd}\left(\mathrm{CH}_{3} \mathrm{COO}\right)_{2}\right](300 \mathrm{mg}, 1.34 \mathrm{mmol})$ and $2(862 \mathrm{mg}, 1.34$ $\mathrm{mmol})$ in acetone $(80 \mathrm{~mL})$ was stirred at room temperature for $24 \mathrm{~h}$. Afterward, the solvent was removed under vacuum, and product 3 was isolated, after the addition of diethyl ether, as a yellow solid ( $800 \mathrm{mg}, 1.07 \mathrm{mmol}$ ). Yield: 80\%. Recrystallization was performed from a mixture of acetone-ether. ${ }^{1} \mathrm{H}$ NMR $\left(\right.$ DMSO- $d_{6}, \delta$ ppm, $\left.300 \mathrm{MHz}\right): 7.81\left(\mathrm{~d}, 2 \mathrm{H}, J_{\mathrm{H}-\mathrm{H}}=1.8\right.$; H5Im), 7.63 (d, 2H, $\left.J_{\mathrm{H}-\mathrm{H}}=1.8 ; \mathrm{H} 4 \mathrm{Im}\right), 7.20\left(\mathrm{~m}, 4 \mathrm{H} ; \mathrm{H}_{\mathrm{m}} \mathrm{Ph}\right)$, $6.92\left(\mathrm{~m}, 2 \mathrm{H} ; \mathrm{H}_{\mathrm{p}} \mathrm{Ph}\right), 6.74\left(\mathrm{~m}, 4 \mathrm{H} ; \mathrm{H}_{\mathrm{o}} \mathrm{Ph}\right), 6.60\left(\mathrm{~d}, 1 \mathrm{H}, \mathrm{J}_{\mathrm{H}-\mathrm{H}}\right.$ = 13.3; $\mathrm{CH}_{2}$-bridge $), 6.32\left(\mathrm{~d}, 1 \mathrm{H}, J_{\mathrm{H}-\mathrm{H}}=13.3 ; \mathrm{CH}_{2}\right.$-bridge $)$, $4.20\left(\mathrm{~m}, 4 \mathrm{H} ; \mathrm{N}-\mathrm{CH}_{2} / \mathrm{CH}_{2}-\mathrm{O}\right), 4.07\left(\mathrm{~m}, 2 \mathrm{H} ; \mathrm{CH}_{2}-\mathrm{O}\right)$, $3.72\left(\mathrm{~m}, 2 \mathrm{H} ; \mathrm{N}-\mathrm{CH}_{2}\right) .{ }^{13} \mathrm{C}\left\{{ }^{1} \mathrm{H}\right\}$-APT NMR (DMSO- $d_{6}, \delta$ ppm, $75 \mathrm{MHz}): 169.1$ (s; C2Im), $157.6(\mathrm{~s} ; \mathrm{C} \mathrm{Ph}), 129.5$ (s; $\mathrm{C}_{\mathrm{m}}$ $\mathrm{Ph}), 123.0$ (s; C5Im), 122.6 (s; C4Im), $121.2\left(\mathrm{~s} ; \mathrm{C}_{\mathrm{p}} \mathrm{Ph}\right), 114.5$ (s; $\left.\mathrm{C}_{\mathrm{o}} \mathrm{Ph}\right), 66.7\left(\mathrm{~s} ; \mathrm{CH}_{2}-\mathrm{O}\right), 63.0$ (s; $\mathrm{CH}_{2}$-bridge), 49.4 (s; $\mathrm{N}-\mathrm{CH}_{2}$ ). Anal. Calcd for $\mathrm{C}_{23} \mathrm{H}_{24} \mathrm{I}_{2} \mathrm{~N}_{4} \mathrm{O}_{2} \mathrm{Pd}$ : C, 36.80; H, 3.49; N: 7.47. Found: C, 36.62; H, 3.14; N, 7.39.

Instrumentation. ${ }^{1} \mathrm{H}$ NMR and ${ }^{13} \mathrm{C}\left\{{ }^{1} \mathrm{H}\right\}$-APT NMR spectra were recorded on a Bruker ARX $300 \mathrm{MHz}$ spectrometer. Chemical shifts are given as dimensionless $\delta$ values. The spectra were referenced to the corresponding residual solvent peaks or to sodium 3-(trimethylsilyl)propanesulfonate (TSP), used as an internal reference for $\mathrm{D}_{2} \mathrm{O}$ measurements. Coupling constants, $J$, are given in hertz. 
Identification of signals was achieved by ${ }^{1} \mathrm{H}-{ }^{13} \mathrm{C}$ HSQC/ HMBC experiments (Supporting Information). The $\mathrm{pD}$ values of the NMR samples were measured by a glass electrode and adjusted by the addition of $\mathrm{NaOD}$ or $\mathrm{DNO}_{3}$.

Determination of $\mathrm{p} K_{\mathrm{a}}$ Values. Acidity constants were determined by $\mathrm{pH}$-dependent ${ }^{1} \mathrm{H}$ NMR spectroscopy. Chemical shift variations were registered at different $\mathrm{pD}$ values. These were obtained by adding 0.4 units to the $\mathrm{pH}$ meter reading (uncorrected $\mathrm{pH}^{*}$ ). $\mathrm{pD}$ was evaluated versus the chemical shift values by a nonlinear least-squares fit according to the Newton-Gauss method. ${ }^{18}$ The obtained $\mathrm{p} K_{\mathrm{a}}$ values (for $\mathrm{D}_{2} \mathrm{O}$ ) were converted to values valid for $\mathrm{H}_{2} \mathrm{O} .{ }^{25}$

X-ray Crystallography. Crystal data and refinement parameters for $\mathbf{1 a}, \mathbf{1 b}, \mathbf{2}$, and $\mathbf{3}$ were collected on an APEX-II diffractometer with graphite monochromated Mo K $\alpha$ radiation $(0.71073 \AA)$. Data reduction and cell refinements were carried out with the APEX2 software package. ${ }^{26}$ The structures were solved by direct methods and refined by full-matrix leastsquares on the basis of $F^{2}$ using the SHELXL-97 and WinGX software. ${ }^{27,28}$ All nonhydrogen atoms were located from difference Fourier maps and were refined anisotropically. Protons were either observed in the difference Fourier map $(\mathbf{1 a}, \mathbf{1 b})$ or positioned geometrically $(2,3)$, and they were refined with isotropic displacement parameters following a riding model. Calculations were performed using the SHELXL97 and WinGX programs.

Crystal Data for PhOEtIm (1a). $\left[\mathrm{C}_{11} \mathrm{H}_{12} \mathrm{~N}_{2} \mathrm{O}\right]$, orthorhombic, P2(1)2(1)2(1), $a=5.5786(8) \AA, b=7.5398(11) \AA ̊, c=$ 23.223(4) $\AA, Z=4, M_{\mathrm{r}}=188.23, V=976.8(2) \AA^{3}, D_{\text {calcd }}=$ $1.280 \mathrm{~g} \mathrm{~cm}^{-3}, \lambda(\mathrm{Mo} \mathrm{K} \alpha)=0.71073 \AA, T=100 \mathrm{~K}, \mu=0.084$ $\mathrm{mm}^{-1}, 12922$ reflections collected, 2590 unique $\left(R_{\text {int }}=\right.$ $0.0627), 2136$ observed, $R 1\left(F_{\mathrm{o}}\right)=0.0451[I>2 \sigma(I)]$, wR2 $\left(F_{\mathrm{o}}^{2}\right)=0.1209$ (all data), GOF $=1.068$. CCDC 1530558 .

Crystal Data for [HPhOEtIm]BF 4 (1b). $\left[\mathrm{C}_{11} \mathrm{H}_{13} \mathrm{BF}_{4} \mathrm{~N}_{2} \mathrm{O}\right.$ ], monoclinic, $P 21 / c, a=5.6463(3) \AA, b=8.2933(4) \AA, c=$ 26.5684(14) $\AA, \beta=93.6800(10)^{\circ}, Z=4, M_{\mathrm{r}}=276.04, V=$ $1241.54(11) \AA^{3}, D_{\text {calcd }}=1.477 \mathrm{~g} \mathrm{~cm}^{-3}, \lambda($ Mo K $\alpha)=0.71073 \AA$, $T=100 \mathrm{~K}, \mu=0.135 \mathrm{~mm}^{-1}, 15747$ reflections collected, 2449 unique $\left(R_{\text {int }}=0.0311\right), 1989$ observed, $R 1\left(F_{\mathrm{o}}\right)=0.0417[I>$ $2 \sigma(I)], \mathrm{wR} 2\left(F_{\mathrm{o}}^{2}\right)=0.1071$ (all data), GOF $=1.069$. CCDC 1530559.

Crystal Data for $\left[\mathrm{H}_{2} \text { bisPhOEtIm] }\right]_{2}$ (2). $\left[\mathrm{C}_{23} \mathrm{H}_{26} \mathrm{I}_{2} \mathrm{~N}_{4} \mathrm{O}_{2}\right]$, monoclinic, $C 2 / c, a=36.0917(15) \AA, b=5.1773(2) \AA, c=$ 13.8210(6) $\AA, \beta=91.5830(10)^{\circ}, Z=4, M_{\mathrm{r}}=644.28, V=$ $2581.57(18) \AA^{3}, D_{\text {calcd }}=1.658 \mathrm{~g} \mathrm{~cm}^{-3}, \lambda($ Mo K $\alpha)=0.71073 \AA$, $T=100 \mathrm{~K}, \mu=2.461 \mathrm{~mm}^{-1}, 15708$ reflections collected, 3108 unique $\left(R_{\text {int }}=0.0229\right), 2797$ observed, $R 1\left(F_{\mathrm{o}}\right)=0.0209[I>$ $2 \sigma(I)]$, wR2 $\left(F_{\mathrm{o}}^{2}\right)=0.0698$ (all data), GOF $=0.991$. CCDC 1530560.

Crystal Data for [Pd(bisPhOEt/m)I $I_{2}$ (3). [ $\mathrm{C}_{23} \mathrm{H}_{24} \mathrm{I}_{2} \mathrm{~N}_{4} \mathrm{O}_{2} \mathrm{Pd}$ ], monoclinic, $P 21 / c, a=9.9925(6) \AA$, $b=17.2375(10) \AA, c=$ 14.6398(8) $\AA, \beta=94.8950(10)^{\circ}, Z=4, M_{\mathrm{r}}=748.66, V=$ 2512.4(3) $\AA^{3}, D_{\text {calcd }}=1.979 \mathrm{~g} \mathrm{~cm}^{-3}, \lambda(\mathrm{Mo} \mathrm{K} \alpha)=0.71073 \AA, T$ $=100 \mathrm{~K}, \mu=3.223 \mathrm{~mm}^{-1}$, 59437 reflections collected, 6184 unique $\left(R_{\text {int }}=0.0429\right)$, 5285 observed, $R 1\left(F_{\mathrm{o}}\right)=0.0311[I>$ $2 \sigma(I)]$, wR2 $\left(F_{\mathrm{o}}^{2}\right)=0.1001$ (all data), GOF $=1.041$. CCDC 1530561 .

Quantum Chemical Calculations. DFT calculations were performed to calculate the energy minima of the systems and the resulting molecular geometries, providing, therefore, good models for comparison with the crystallographically determined data. The $\mathrm{M} 1 \mathrm{~L}^{29}$ functional was utilized, through the polarizable continuum method (SMD). ${ }^{30}$ The basis sets used for $\mathrm{C}, \mathrm{N}, \mathrm{O}$, and $\mathrm{H}$ were $6-311++\mathrm{G}(\mathrm{d}, \mathrm{p})$. Pd and I were represented with the use of the relativistic effective core potential from the Stuttgart group. ${ }^{31,32}$ All calculations were performed with the Gaussian09 software. ${ }^{33} \mathrm{NICS}^{34}$ values were computed using the Gauge-including atomic orbital method at the same level of theory, ${ }^{35,36}$ either at the geometrical center of the rings $(\mathrm{NICS}(0))$ or above the perpendicular plane of the rings (at $1.0 \AA, \operatorname{NICS}(1)$ ). Coordinates are given in the Supporting Information.

\section{ASSOCIATED CONTENT}

\section{Supporting Information}

The Supporting Information is available free of charge on the ACS Publications website at DOI: 10.1021/acsomega.7b00138.

Structural data, NMR spectra, and computational details (PDF)

X-ray diffraction records (CCDC 1530558-1530561) (CIF) (CIF) (CIF) (CIF)

\section{AUTHOR INFORMATION}

\section{Corresponding Author}

*E-mail: pablo.sanz@unizar.es.

ORCID $\odot$

Pablo J. Sanz Miguel: 0000-0002-8220-6031

Present Address

${ }^{\dagger}$ Departamento de Química, Universidad de La Rioja, 26004 Logroño, Spain (M.G.-M.).

Notes

The authors declare no competing financial interest.

\section{ACKNOWLEDGMENTS}

Financial support from the University of Zaragoza (UZ2015CIE-09) is kindly acknowledged. A.V. thanks the Aragón Government for a predoctoral fellowship.

\section{ADDITIONAL NOTES}

${ }^{a}$ A search in the CSD database (February 1, 2017) sheds 1792 hits with at least a trans $\mathrm{L}-\mathrm{Pd}-\mathrm{L}$ angle $<164.6^{\circ}$, out of a total of 16786 hits (PdL4, L = any atom).

${ }^{b}$ Search in the CSD database (February 1, 2017).

\section{REFERENCES}

(1) See, e.g.: Hopkinson, M. N.; Richter, C.; Schedler, M.; Glorius, F. An overview of N-heterocyclic carbenes. Nature 2014, 510, 485-496 and refs. cited.

(2) Ezugwua, C. I.; Kabira, N. A.; Yusubovc, M.; Verpoort, F. Metalorganic frameworks containing $\mathrm{N}$-heterocyclic carbenes and their precursors. Coord. Chem. Rev. 2016, 307, 188-210.

(3) Mercs, L.; Albrecht, M. Beyond catalysis: N-heterocyclic carbene complexes as components for medicinal, luminescent, and functional materials applications. Chem. Soc. Rev. 2010, 39, 1903-1912.

(4) Curran, D. P.; Solovyev, A.; Brahmi, M. M.; Fensterbank, L.; Malacria, M.; Lacôte, E. Synthesis and Reactions of N-Heterocyclic Carbene Boranes. Angew. Chem., Int. Ed. 2011, 50, 10294-10317.

(5) Enders, D.; Niemeier, O.; Henseler, A. Organocatalysis by NHeterocyclic Carbenes. Chem. Rev. 2007, 107, 5606-5655.

(6) Bourissou, D.; Guerret, O.; Gabbaï, F. P.; Bertrand, G. Stable Carbenes. Chem. Rev. 2000, 100, 39-91.

(7) Jahnke, M. C.; Hahn, F. E. Complexes with protic (NH,NH and NH,NR) N-heterocyclic carbene ligands. Coord. Chem. Rev. 2015, 293-294, 95-115.

(8) Vellé, A.; Cebollada, A.; Iglesias, M.; Sanz Miguel, P. J. Argentophilicity as Essential Driving Force for a Dynamic Cation- 
Cation Host-Guest System: $\left[\mathrm{Ag}(\text { acetonitrile })_{2}\right]^{+} \subset\left[\mathrm{Ag}_{2}(\text { bis-NHC })_{2}\right]^{2+}$ $(\mathrm{NHC}=\mathrm{N}-$ Heterocyclic Carbene $)$. Inorg. Chem. 2014, 53, 1065410659 .

(9) Cebollada, A.; Vellé, A.; Iglesias, M.; Fullmer, L. B.; GobernaFerrón, S.; Nyman, M.; Sanz Miguel, P. J. Direct X-Ray Scattering Evidence for Metal-Metal Interactions in Solution at the Molecular Level. Angew. Chem., Int. Ed. 2015, 54, 12762-12766.

(10) Herrmann, W. A. N-Heterocyclic Carbenes: A New Concept in Organometallic Catalysis. Angew. Chem., Int. Ed. 2002, 41, 1290-1309.

(11) Ernst, J. B.; Muratsugu, S.; Wang, F.; Tada, M.; Glorius, F. Tunable Heterogeneous Catalysis: N-Heterocyclic Carbenes as Ligands for Supported Heterogeneous $\mathrm{Ru} / \mathrm{K}-\mathrm{Al}_{2} \mathrm{O}_{3}$ Catalysts to Tune Reactivity and Selectivity. J. Am. Chem. Soc. 2016, 138, 10718-10721.

(12) For a recent review, see: Liu, W.; Gust, R. Update on metal Nheterocyclic carbene complexes as potential anti-tumor metallodrugs. Coord. Chem. Rev. 2016, 329, 191-213.

(13) Würtemberger-Pietsch, S.; Radius, U.; Marder, T. B. 25 years of N-heterocyclic carbenes: activation of both main-group elementelement bonds and NHCs themselves. Dalton Trans. 2016, 45, 58805895.

(14) Wang, G.; Rühling, A.; Amirjalayer, S.; Knor, M.; Ernst, J. B.; Richter, C.; Gao, H.-J.; Timmer, A.; Gao, H.-Y.; Doltsinis, N. L.; Glorius, F. Ballbot-type motion of N-heterocyclic carbenes on gold surfaces. Nat. Chem. 2017, 9, 152-156.

(15) See, e.g.: Flanigan, D. M.; Romanov-Michailidis, F.; White, N. A.; Rovis, T. Organocatalytic Reactions Enabled by N-Heterocyclic Carbenes. Chem. Rev. 2015, 115, 9307-9387.

(16) See, e.g.: Fèvre, M.; Pinaud, J.; Gnanou, Y.; Vignolle, J.; Taton, D. N-Heterocyclic carbenes (NHCs) as organocatalysts and structural components in metal-free polymer synthesis. Chem. Soc. Rev. 2013, 42, 2142-2172.

(17) Hollóczki, O.; Nyulászi, L. Carbenes from Ionic Liquids. Top. Curr. Chem. 2014, 351, 1-24.

(18) Tribolet, R; Sigel, H. Self-association and protonation of adenosine $5^{\prime}$-monophosphate in comparison with its $2^{\prime}$ - and $3^{\prime}$ analogues and tubercidin $5^{\prime}$-monophosphate (7-deaza-AMP). Eur. J. Biochem. 1987, 163, 353-363.

(19) Albert, A. Heterocyclic Chemistry: an Introduction, 2nd ed.; Athlone Press: London, 1968.

(20) Cordero, B.; Gómez, V.; Platero-Prats, A. E.; Revés, M.; Echeverría, J.; Cremades, E.; Barragán, F.; Álvarez, S. Covalent radii revisited. Dalton Trans. 2008, 2832-2838 and refs. cited..

(21) See, e.g.: Vellé, A.; Cebollada, A.; Ruiz, S.; Fonseca Guerra, C.; Sanz Miguel, P. J. Crystallographic and Computational Study on Cationic Triply Hydrogen-Bonded Nucleobases without Direct Anionic Stabilization. Cryst. Growth Des. 2015, 15, 5873-5878 and refs. cited..

(22) Preut, H.; Fischer, B.; Lippert, B. 9-Ethylguaninium Tetrachloroaurate(III) Hydrate. Acta Crystallogr., Sect. C: Cryst. Struct. Commun. 1990, 46, 1115-1117.

(23) Aliaga-Lavrijsen, M.; Iglesias, M.; Cebollada, A.; Garcés, K.; García, N.; Sanz Miguel, P. J.; Fernández-Alvarez, F. J.; PérezTorrente, J. J.; Oro, L. A. Hydrolysis and Methanolysis of Silanes Catalyzed by Iridium(III) Bis-N-Heterocyclic Carbene Complexes: Influence of the Wingtip Groups. Organometallics 2015, 34, 23782385.

(24) Cebollada, A.; Vellé, A.; Sanz Miguel, P. J. Hirshfeld and DFT analysis of the $\mathrm{N}$-heterocyclic carbene proligand methylenebis $(\mathrm{N}$ butylimidazolium) as the acetonitrile-solvated diiodide salt. Acta Crystallogr., Sect. C: Cryst. Struct. Commun. 2016, 72, 456-459.

(25) Martin, R. B. Deuterated Water Effects on Acid Ionization Constants. Science 1963, 139, 1198-1203.

(26) APEX2; Bruker-AXS: Madison, Wisconsin, 2011.

(27) Sheldrick, G. M. SHELXS-97 and SHELXL-97; University of Göttingen: Germany, 1997.

(28) Farrugia, L. J. WinGX; University of Glasgow: Great Britain, 1998.
(29) Peverati, R.; Truhlar, D. G. M11-L: A Local Density Functional That Provides Improved Accuracy for Electronic Structure Calculations in Chemistry and Physics. J. Phys. Chem. Lett. 2012, 3, 117124.

(30) Marenich, A. V.; Cramer, C. J.; Truhlar, D. G. Universal Solvation Model Based on Solute Electron Density and on a Continuum Model of the Solvent Defined by the Bulk Dielectric Constant and Atomic Surface Tensions. J. Phys. Chem. B 2009, 113, 6378-6396.

(31) Andrae, D.; Haussermann, U.; Dolg, M.; Stoll, H.; Preuss, H. Energy-adjusted ab initio pseudopotentials for the second and third row transition elements. Theor. Chim. Acta 1990, 77, 123-141.

(32) Dolg, M.; Stoll, H.; Preuss, H.; Pitzer, R. M. Relativistic and correlation effects for element 105 (hahnium, $\mathrm{Ha}$ ): a comparative study of $\mathrm{M}$ and $\mathrm{MO}(\mathrm{M}=\mathrm{Nb}, \mathrm{Ta}, \mathrm{Ha})$ using energy-adjusted ab initio pseudopotentials. J. Phys. Chem. 1993, 97, 5852-5859.

(33) Frisch, M. J.; Trucks, G. W.; Schlegel, H. B.; Scuseria, G. E.; Robb, M. A.; Cheeseman, J. R.; Scalmani, G.; Barone, V.; Mennucci, B.; Petersson, G. A.; Nakatsuji, H.; Caricato, M.; Li, X.; Hratchian, H. P.; Izmaylov, A. F.; Bloino, J.; Zheng, G.; Sonnenberg, J. L.; Hada, M.; Ehara, M.; Toyota, K.; Fukuda, R.; Hasegawa, J.; Ishida, M.; Nakajima, T.; Honda, Y.; Kitao, O.; Nakai, H.; Vreven, T.; Montgomery, J. A., Jr.; Peralta, J. E.; Ogliaro, F.; Bearpark, M.; Heyd, J. J.; Brothers, E.; Kudin, K. N.; Staroverov, V. N.; Kobayashi, R.; Normand, J.; Raghavachari, K.; Rendell, A.; Burant, J. C.; Iyengar, S. S.; Tomasi, J.; Cossi, M.; Rega, N.; Millam, J. M.; Klene, M.; Knox, J. E.; Cross, J. B.; Bakken, V.; Adamo, C.; Jaramillo, J.; Gomperts, R.; Stratmann, R. E.; Yazyev, O.; Austin, A. J.; Cammi, R.; Pomelli, C.; Ochterski, J. W.; Martin, R. L.; Morokuma, K.; Zakrzewski, V. G.; Voth, G. A.; Salvador, P.; Dannenberg, J. J.; Dapprich, S.; Daniels, A. D.; Farkas, Ö.; Foresman, J. B.; Ortiz, J. V.; Cioslowski, J.; Fox, D. J. Gaussian 09; Gaussian, Inc.: Wallingford, CT, 2009.

(34) Schleyer, P. v. R.; Maerker, C.; Dransfeld, A.; Jiao, H.; Hommes, N. J. R. v. E. Nucleus-Independent Chemical Shifts: A Simple and Efficient Aromaticity Probe. J. Am. Chem. Soc. 1996, 118, 6317-6318.

(35) Ditchfield, R. Molecular Orbital Theory of Magnetic Shielding and Magnetic Susceptibility. J. Chem. Phys. 1972, 56, 5688-5691.

(36) Wolinski, K.; Hinton, J. F.; Pulay, P. Efficient implementation of the gauge-independent atomic orbital method for NMR chemical shift calculations. J. Am. Chem. Soc. 1990, 112, 8251-8260. 